\title{
CORPORATE IMAGE BUILDING THROUGH HR PRACTICES: A COMPARATIVE STUDY ON IT COMPANIES IN INDIA
}

\author{
RENU RANA \& DR. SHIKHA KAPOOR
}

Amity University, Noida, India

\begin{abstract}
This paper represents the impact of HR Practices on Corporate Image Building and shows the results of survey did on five selective IT Companies in India. The Survey was conducted on two hundred IT employees in the selected IT Companies showing that there is a strong relationship between HR Practices and Corporate Image Building respectively. The survey conducted on IT Companies suggested the new and creative HR Practices to build the strong Corporate Image. Further, those practices would be suggested to the IT leaders to consider and impose in their organization for building strong image in the competitive business market and invest more on manpower/human resource to gain the competitive advantage and good revenues in future.

KEYWORDS: HR Practices, Corporate Image Building, IT Companies, Human Resource
\end{abstract}

Received: Jun 09, 2020; Accepted: Jun 29, 2020; Published: Aug 06, 2020; Paper Id.: IJMPERDJUN2020648

\section{INTRODUCTION}

Indian IT Companies have learnt many HR Practices and imposed many creative ideas from all over the world in the last years. IT Sector in India contributed so well in terms of growth and development of the economy. One of the large benefits it provides to the country is the high employment rate in the last five years. There are 3 to 3.1 million (Approx.) IT employees are working in India (NASCOM, 2017). This is the calculation of directly employed employees, whereas the indirectly employed employees would be more. In private sector, Indian IT companies proved as the best employer in the country. The IT manpower mainly works as engineers, software developers, testers and in support with HR, Operations and Marketing.

HR Practices in IT Sector plays an integral role in developing an innovative and creative environment in the organization. HR Practices prime focus is the optimum utilization of human resource and to achieve the maximum productivity in the firm. S. Khan, 2016 signifies that to implement the best HR Practices, there is a need of healthy and energetic business atmosphere in the organization. HR Practices specifically includes the policies, practices and activities that comprises planning, organizing, developing, utilizing and retaining the satisfied manpower to achieve the company's goals. Effective HR Practices are advantageous in the constructive growth of the organization and helps in creating good revenues.

HR Practices in IT companies is much needed for organizing the resources in a better way. HR leaders wear different hats and manage so many responsibilities -starts from recruitment and ends to retirement. The HR department always inundated with so many activities like talent acquisition, compliance processes, payroll processes, talent management, training and development and many more. Out of all, recruiting the top talent would be the most difficult task the HR leaders facing today (ICIMS Survey, 2019). Whereas the other challenges are 
executing continuous compliance, managing employee benefits and employee retention.

Investing in human resource would always beneficial for the organization. A satisfied employee always perform better and helps the organization in achieving its goals easily. Lamba and Chaudhary (2013) elaborated that HR Practices is an edge to employee's dedication towards their job. HR Practices like compensation, training and development and welfare activities helps in retaining the knowledgeable and skilled manpower. Companies, who easily retain their talent for long and get their employee satisfied would achieve many benefits in terms of good image and can easily handle their company's brand effectively. Building the corporate image is not an easy task, it required lots of resources and their utilization in a better way to impose all practices and policies to get that competitive edge to create and maintain the best name in the market. Thus, the aim of this study is to examine the impact of HR Practices on Corporate Image Building in Indian IT Sector using selected IT Companies as a case study. The choice of IT Companies was based on the fact that these IT Companies have large pool of employees and they have known for best HR atmosphere with effective practices and policies in their organization. However, there are many IT Companies in India who is doing wonder in terms of HR Practices but are not captured in this study.

Moreover, this study would be able to answer the following research questions.

- Is there is a significant relationship between HR Practices and Corporate Image Building.

- Does employees are satisfied with the HR Practices in IT Companies?

- Does human resource contribute in the Corporate Image Building of the organization?

- Does IT Companies invest in the career development of their employees?

\section{LITERATURE REVIEW}

\section{HR Practices}

Human resource is the most important source of competitive advantage and an asset to the organization. Managing HR is the most difficult job in the organization and for its effective management, companies need an effective HR System. HR System consists of various sound HR Practices. Those practices are useful in managing the human resource and motivating employees to attain the goal of the organization (P. Tiwari, 2015). HR Practices would mostly depend on the different variables of the organization mainly employee's attitude and behavior, relationships among employees, organization image, company's financial status and many more. HR is the resource that can convert the other resources into money (Profits). Managers can easily handle the other resources of the organization but managing human resource is the most difficult task to do. It requires many effective and efficient skills, practices and policies to plan the strategy of managing the manpower (R. Rana, et al.)

The survival and growth are become difficult in this competitive business market, as day by day the advancement in technology and the global practices have been eliminating the seats of human in the companies. And because of this competitive environment many companies have started giving attention to their Net Promoter Score (NPS) and investing more resources on managing their employees to make them productive and efficient (Hamid, 2016). In IT industry, one should take the benefit of technology in human resource management. At present, the way of doing administration work has totally changed. Registers and files have been replaced with computers and software's. The HR manager with IT department can do wonders and make HR Practices so easy and reliable. 
Employees who are satisfied with HR Practices of their organization will get retained and do help in creating the good image of the organization (Osbanjio, 2015). Not every employee would work for salaries, some need peaceful job, good working atmosphere, brand image, incentives, recognition, stress free work, etc. Therefore, the organization should differentiate themselves as the best organization depends upon their SWOT (Strength, Weakness, Opportunities and Threats). This will help them in creating the different brand in the eyes of future applicants. Though it requires effective planning, strategy and well draft policies for their employees and lastly the sound HR System who can impose those practices in the organization.

Employees are not always motivated with the monetary benefits, sometimes their involvement in decision making, being part of the organizing team, recognition and rewards can act as a best driver of their motivation (Gallup, 2015). Some of them working for learning new skills from their managers, the best managers always share their knowledge and experience with the team-mates. Good leaders make their employees capable to perform the same task in their absence and delegate their duties to them. Moreover, employees need opportunities to learn and grow in their respective field of work. In 2016, number of IT organization focused on talent management, they introduced a new department in their HR System to manage the talent of their employees in a better way (Economic Times, 2016). The main reason behind this is to check the capability of their employees, so that organization can easily plan for their future goals. To implement a new business strategy, it is important to develop the right talent so that they can easily perform the future job with full commitment. Overall, there are so many variables that can be considered while designing the best HR Practices for the future employees.

\section{Best HR Practices}

To achieve the targets and benefits, organization must implement the best HR Practices for their employees based upon their strength and weaknesses. Empstrack (An HR Solution Organization), 2019 did a survey to identify the best HR Practices for the employees and they concluded that the best HR Practices are: 


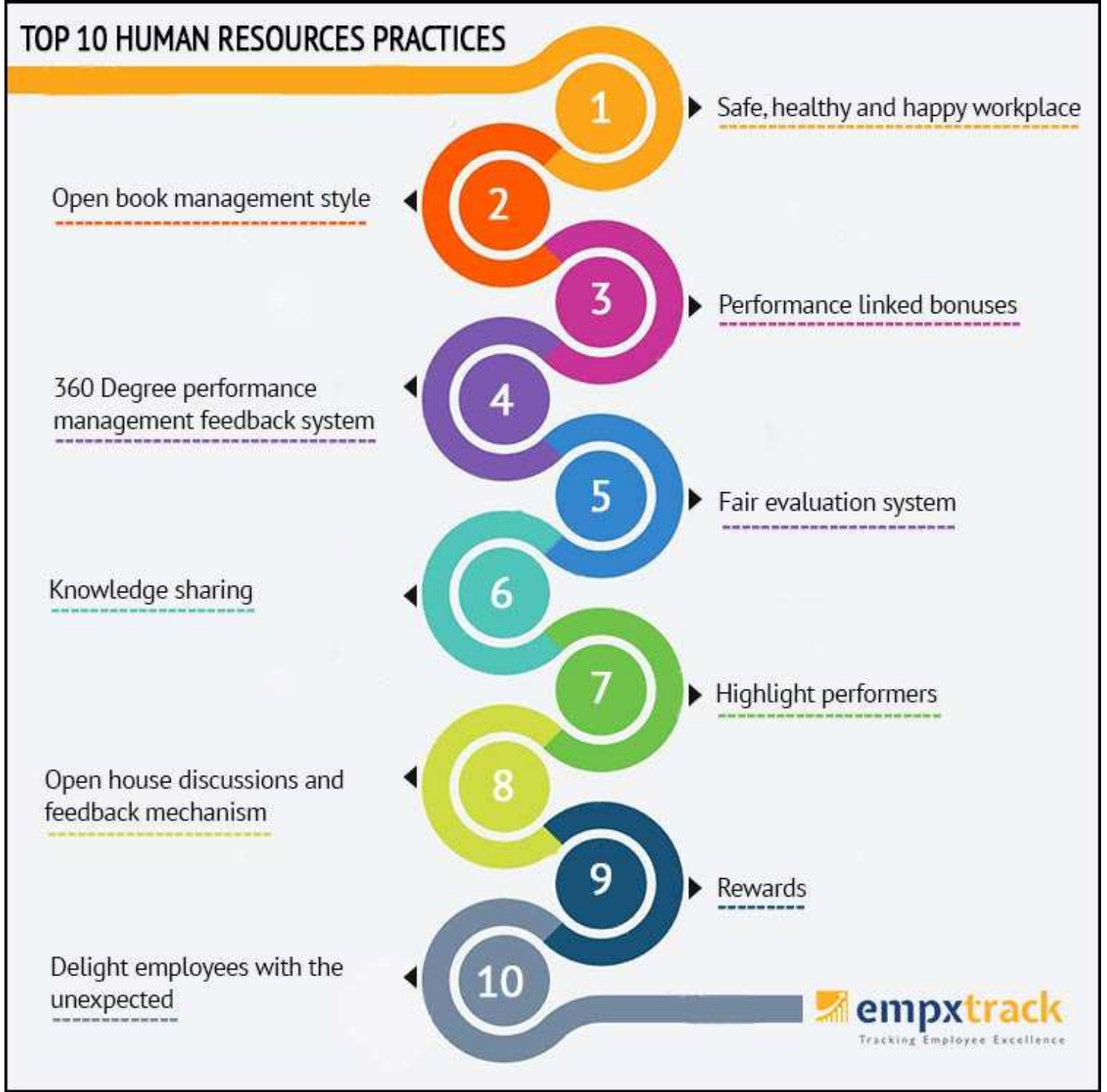

Figure 1: Top Ten HR Practices (Source: Empxtrack Survey, 2019).

- Safe, Healthy and Happy Workplace: Employees feel happy and stress free, if their organization provides a happy, healthy and safe workplace to them. Frequent tea breaks, happy hours, team lunch, weekly dinner parties, movie sessions, art and fun, casual meetings, etc. are the practices that help the HR managers in making their employees stress free and happy sometimes. IT Companies like Google, Wipro, Accenture, Infosys and many more have imposed such practices in their campus and got excellent results in the productivity of their employees. Such practices help the organization in attracting and retaining the best talent for long.

- Open Book Management Style: Sharing the management objectives, values and goals, information like total sales, management policies, employee personal data, etc. ensures that the manpower is enthusiastic and feels a part of management. This way employee puts his/her interest completely in achieving the organization targets. Online HR portals, ERP Software, and many more tools are available today to practice such styles effectively.

- Performance Linked Bonus: The monetary rewards like performance bonus, team targets and token compensation motivate employee to perform better and can enhance their skills while working for team success to achieve the team targets. This practice does helps in employee retention and motivation. 
- 360 Degree Performance Management Feedback System: For collecting the employee performance feedback, this system proved as best and transparent. Taking feedback from seniors, peers and subordinates has been embraced as the best method of taking the employee feedback. Every member of the team gives relevant and constructive feedback to their teammates.

- Fair Evaluation System: An organization should have an evaluation system that can directly link the employee performance to the company's goals and objectives. Every employee has a properly defined hierarchy to report and discuss the objectives. Self-rating must be the part of evaluation system. Evaluation system should be fair and just to evaluate the accurate performance of the employee every year.

- Knowledge Sharing: An organization should adopt an approach where knowledge management would be directly proportional to the company strategy. The knowledge database should be accessible to the employees of the company. There should a knowledge sharing platform, where employees can easily share innovative ideas, practices or plans with each other. However, it requires proper planning to impose such practice within the organization.

- Highlight Performs: Encouraging best employees by highlighting their profiles on companies' portals motivate other employees to perform better and best within the competitive environment of the company.

- Feedback Mechanism and Open House Discussion: Sound organizations recognize and execute great ideas, and those ideas ruled the world. Employee -Management meetings, open house discussion, feedback mechanism, suggestion boxes, etc. can help in identifying many new ideas and talents of the employees.

- Rewards: Not all employees motivate with monetary rewards. Sometimes recognition in public forum and thunderous applause by colleagues is more significant and needed. A reward timely is necessary to bring out the best of the employees. Many organizations have effective reward system for their employees and indirectly it leads to company's profit.

- Delight Employees with the Unexpected: At last, the other important HR Practice to be imposed is to delight the best employees with unexpected like certificate ceremony, gifts, vacations, etc. can be the part of reward for the company's employees. Also, the other employees should be rewarded sometimes as a token of motivation.

\section{Corporate Image Building and HR Practices}

The concept of corporate image is latest and wide, it arises from theory of marketing. Positive attitude of present and potential employees/ consumers is must for corporate image building. Corporate image is comprised of building a positive corporate personality, creating marketing and communication channels and taking constant feedback from consumers. Worcesfer, Mechan et al., Torres and many more emphasize the significance and importance of corporate image building. Positive corporate image provides effective features to companies that leads to corporate reputation, brand recognition, consumer trust and employee loyalty. Yeo \& Yousef, 2009 states that Corporate Image act as a source of competitive advantage and it takes time to build it, somehow difficult to imitate.

Corporate Image helps in receiving the sales volume, increasing customer loyalty and also helps in attracting the potential investors and employees. Corporate Image is dynamic in nature and can be change because of many reasons like shift in consumers behavior and attitude, events and activities of organization, etc. (LeBlane \& Ngugen, 2005). It has been 
found that companies who easily adopt change are innovative and creative in all aspects. Edvardsson and Strandvik, 2010 states that if companies have an interaction with their consumers, it will lead to stronger corporate image.

The literature found on corporate image building is majorly signifies that the concept of corporate image is related to number of variables exist in organization. The objective of this paper is to find the relationship between HR Practices and Corporate Image Building. HR Practices have been previously described in the literature and the data signifies that HR Practices can be one of the significant factors of corporate image building. Manpower is one of the most important resource in the organization and capable enough to convert the other resources into profits. To check the role of HR practices in corporate image building a survey was conducted in IT companies in India which includes the top IT leaders like Infosys, Accenture, TCS, IBM and HCL. The case was studied and concluded further in this study.

\section{Company Profiles}

\section{Infosys}

Infosys Limited in India is one of the top Indian multinational corporations and provides IT services like business consulting, software engineering, business consulting and outsourcing services. Its main head quarter is in Bangalore, Karnataka. It is the second largest IT service-based company in India and also the fifth largest employer. The total number of employees in Infosys was 176,187 (March, 2019).

\section{TCS}

In technology sector, TCS is one of the world largest employer with around three lakhs employees. The company reports signify that it has more than 3 lakhs employees spread over 46 countries. As per the records, TCS expected to hire around 60,000 employees in the present year (Economic Times, 2020).

\section{IBM}

The International Business Machine Corporation is an American Multinational Organization head quartered in New York. IBM India Pvt. Ltd. is a subsidiary of IBM and head quartered in Bangalore, India. The total number of employees exist is 350000. IBM India reach such heights where they pose to homegrown the software development companies all around the world.

\section{Accenture}

Accenture counted on the top tech employer in India. With around 250000 employees, Accenture is known for its best HR practices for the employees. The company also announced to hire around 80 thousand employees in the financial year 2019, however the exact data is note reviled till date.

\section{HCL}

Hindustan Computers Limited is an Indian global IT service company head quartered in Noida, Uttar Pradesh. The company offers IT services includes business outsourcing, R\& D services, software consulting, software engineering and business process outsourcing. The present reports states that HCL employs around 120000 employees, out of which 75000 are Indian employees.

These five companies have been selected for the survey and studying the case that how HR practices helps these IT companies in corporate image building and also to know the answers for the research questions. 


\section{RESEARCH METHODOLOGY}

IT companies in India is experiencing rapid growth and large revenues in the recent years. These IT tech leaders employ million of employees all around the world. To identify the relationship between HR Practices and Corporate Image Building, five IT Companies have been randomly selected for data collection.

This research study is a qualitative approach to understand the relationship between HR Practices and corporate image building in Indian IT Sector. Data was collected from five IT companies - HCL, TCS, Infosys, IBM and Accenture. The questionnaire used for this study contains twenty close ended questions related to the variables of the study. Both primary and secondary data was used for this study. Data was personally collected from 200 employees of IT companies and concluded for getting the output of the survey.

\section{DATA ANALYSIS}

\section{Demographic Analysis}

The data was collected from 200 IT employees out of which the questionnaire was filled by $43.5 \%$ females and 53.5\% males' employees. There is a fair distribution of employees in Indian IT sector. Female employees in IT sector have been increasing in good numbers which shows that IT sector must have good policies and practices for female employees in their organization. The data reflects that there are more of young employees working in Indian IT companies, out of 200 employees $93 \%$ are below 40 years of age. Figure 2 shows the demographic description of the survey.
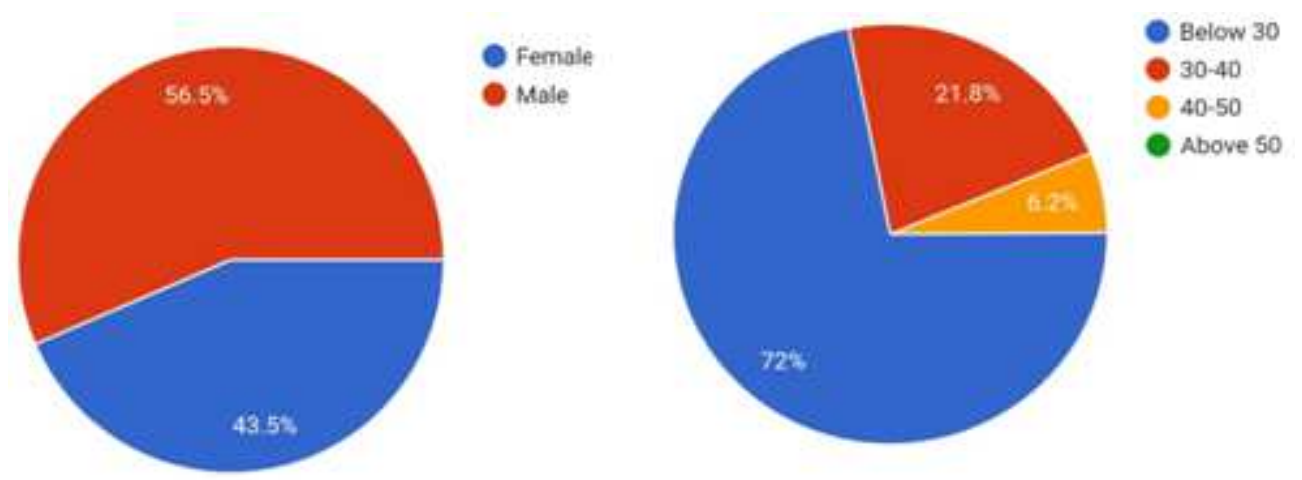

Figure 2: Demographic Discription of the Survey in IT Companies.

The questionnaire include five close ended questions to analyze are the employees are satisfied with the HR practices of their organization. After analyzing those five questions the data revealed that $18.9 \%$ employees are strongly agreed and $49.7 \%$ agreed that they are satisfied with the HR practices of their respective organization, whereas only $8.8 \%$ disagreed from this statement and $19.2 \%$ marked neutral for this statement. 
I, as an employee, feel satisfied with the HR Practices of my organization.

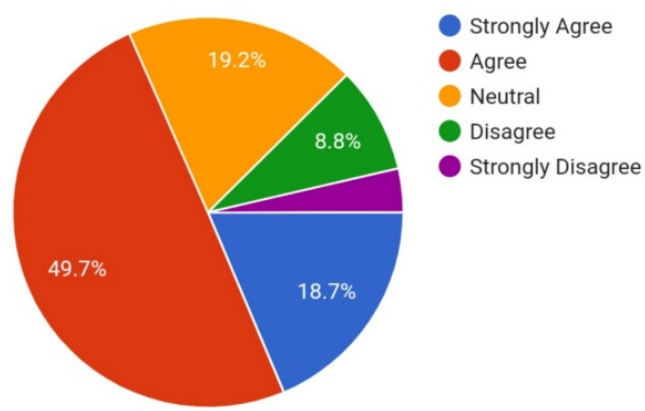

Figure 3: Satisfaction of IT Employees in their Organization.

The next five question of the questionnaire analyzed to find that if employees feel their organization as the best place to work. The data shows that $13.5 \%$ employees are strongly agree and $45.3 \%$ marked agree to this statement. Whereas the rest are falls under the category of disgarred or neutral. Simply means, half of the population still need more to feel their work place as a best place to work.

\section{My organization is the best place to} work.

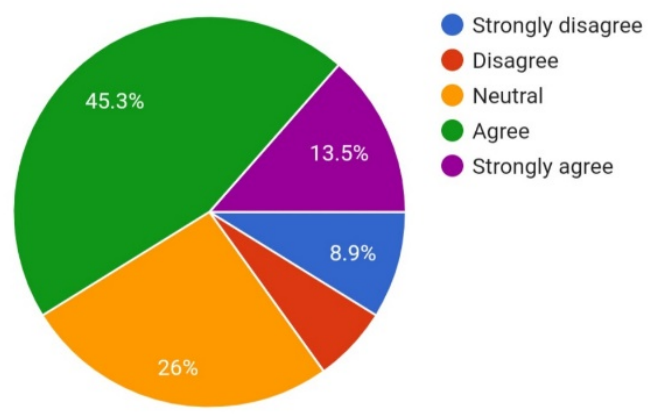

Figure 4: Response- Organization as the Best Place to Work.

Another part of the survey is to analyze that whether the IT companies invest resources in the growth and development of their employees or not. The responses given by the IT employees shows that $13.5 \%$ are strongly agreed that their compnies spend time and money on their growth and development and $47.4 \%$ also marked agreed for this statement. Rest, only $10.9 \%$ employees are stronged disgreed and state that their companies not spend resources in their career development. 
My organization invest both time

and money in the career

development of the employees.

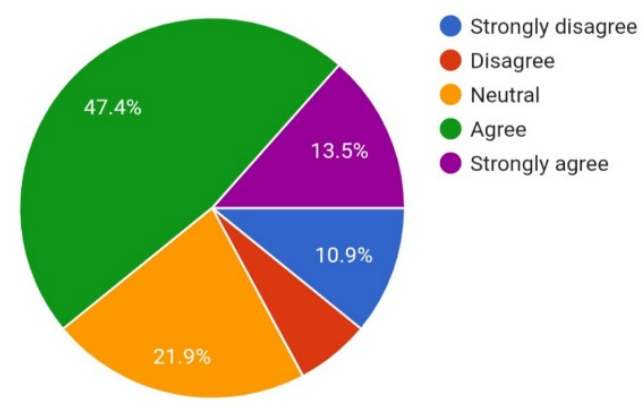

\section{Figure 5: Response: Resource Investment for Employees Career Development.}

When asked about HR contribution in the company's growth and development, the results indicates that more than $80 \%$ employees agreed that they contribute in the compnaies growth and development and no one disagreed to this. However, it is the fact that without human resource no organization can achieve their goals and its only the manpower who converts all resources into money.
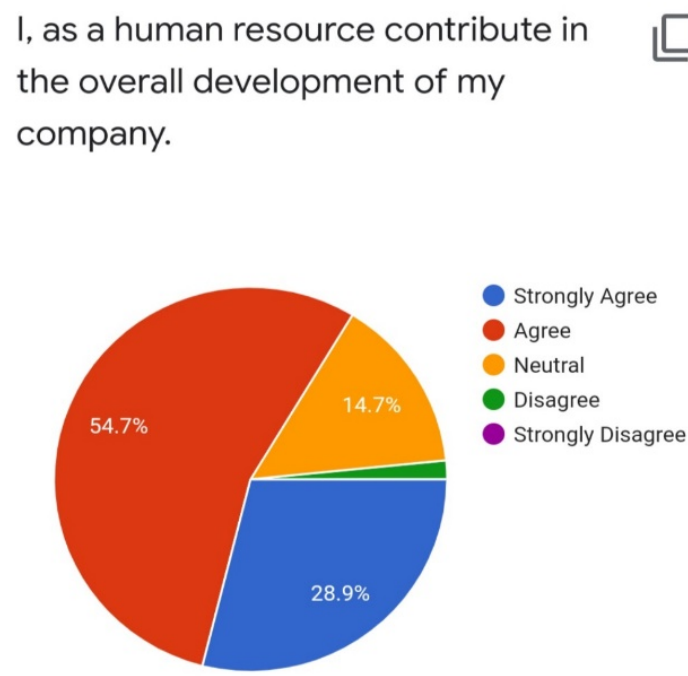

Figure 6: Response- HR Contribution in the Companies Growth and Development.

Another area of research is to know whether the IT employees have embraced that their organization have good image in the market place. The data on this behalf shows that more than $90 \%$ employees marked agreed and they believe that their organization (IBM, HCL, Infosys, Accenture and TCS) have good reputation and brand image. Very few employees disagreed to this statement. These IT tech leaders investing more and performing well for creating and maintaining their corporate image. 
My company has a good self image

in the IT Sector in India.

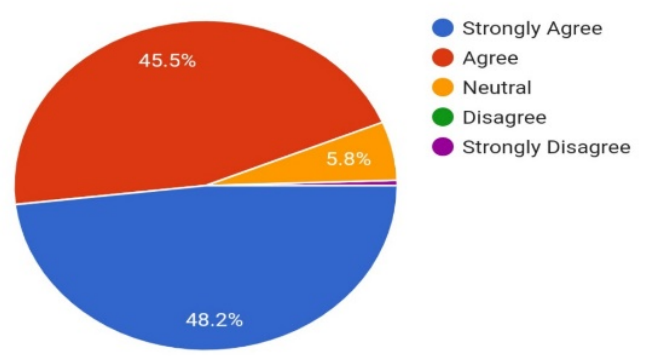

Figure 7: Response- Companies Brand Image.

\section{CONCLUSION}

The results indicates that there is a close relationship between HR Practices and Corporate Image Building. However, the study conclude that half of the population is still not satisfied with the HR Practices of their respective organization. The implication of this study for the IT leaders/ managers is that they should imposed some good and effective HR practices in their organization and that will probably give much better results in manageing their manpower and ultimately leads to good corporate image. Further, the study enhances that IT employees have contributed and they believe that they are main source of companies development, however it can also be analyzed from the managers point of view. The other part of the study conclude that number of IT companies investing time and money in the career development of the employees and this will help the oraganization in retaining the best talent and attracting the future talent towards them. Thus, investing more on HR and providing best HR practices can be one of the best option for corporate image building.

\section{REFERENCES}

1. Carroll, A. B. (1979). A three-dimensional conceptual model of corporate social performance.

2. Academy of Management Review, 4, 497-505.

3. Lakshmi, P., and P. Pratap. "HR analytics-a strategic approach to HR effectiveness." International Journal of Human Resource Management and Research 6.3 (2016): 21-28.

4. Collins, C. J., \& Clark, K. D. (2003) the role of human resource practices in creating organizational competitive advantage. Academy of management Journal, 46(6), 740-751.

5. Employees. Corporate Communications: An International Journal, 17(3), 300-322.

6. Qazi, Sayeeduzzafar, and Mohammad Saleh Miralam. "Human Resources Management Practices and Job Satisfaction in Critical Economy: An Empirical Study of Private Banking Sector of Saudi Arabia." International Journal of Business Management and Research 7.6 (2017): 43-52.

7. Fuentes-García, F. J., Núñez-Tabales, J. M., \&Veroz-Herradón, R. (2008). Applicability of corporate social responsibility to human resources management: Perspective from Spain. Journal of Business Ethics, 82(1), 27-44.

8. Figurska, I., \&Matuska, E. (2013). Employer Branding As a Human Resources Management Strategy. Human resources management \& Ergonomics, 7(2). 
9. Fombrun, C., \& Shanley, M. (1990). What's in a name? Reputation building and corporate strategy. Academy of management Journal, 33(2), 233-258.

10. Madhavi Lakshmi, P., and P. Siva Pratap. "HR Analytics-a Strategic Approach to HR Effectiveness." International Journal of Human Resource Management and Research (IJHRMR) ISSN (P) (2016): 2249-6874.

11. Foster, C., Punjaisri, K., \& Cheng, R. (2010). Exploring the relationship between corporate, internal and employer branding. Journal of Product \& Brand Management, 19(6), 401-409.

12. Goyal, R., \& Shrivastava, M. (2012). A study of HR practices and their impact on employees job satisfaction and organizational commitment in pharmaceuticals industries. International Journal of Business Trends and Technology, 2(3), 2228.

13. Guest, D. (2002). Human resource management, corporate performance and employee wellbeing: Building the worker into HRM. The journal of industrial relations, 44(3), 335-358.

14. Harel, G. H., \&Tzafrir, S. S. (1999). The effect of human resource management practices on the perceptions of organizational and market performance of the firm. Human resource management, 38(3), 185-199.

15. Hussainy, K., Elsayed, M., \&Abdelrazek, M. (2011). Factors affecting corporate social responsibility disclosure in Egypt. Corporate Ownership and Control journal, 1-27.

16. Jeet, V., \&Sayeeduzzafar, D. (2014). A study of HRM practices and its impact on employees job satisfaction in private sector banks: A case study of HDFC Bank. International Journal of Advance Research in Computer Science and Management Studies, 2(1), 62-68.

17. Jo Hatch, M., \& Schultz, M. (1997). Relations between organizational culture, identity and image. European Journal of marketing, 31(5/6), 356-365.

18. Jo Hatch, M., \& Schultz, M. (2003). Bringing the corporation into corporate branding. European Journal of marketing, 37(7/8), 1041-1064.

19. Kim, D., \& Sturman, M. C. (2012). HR branding: How human resources can learn from product and service branding to improve attraction, selection, and retention.

20. Kim, H. R., Lee, M., Lee, H. T., \& Kim, N. M. (2010). Corporate social responsibility and employee-company identification. Journal of Business Ethics, 95(4), 557-569.

21. Maruf, A. A. (2013). Corporate Social Responsibility and Corporate Image. Transnational Journal of Science and Technology, 29.

22. Mahadevan, A., \& Sn Mohamed, F. A. (2014). Impact Of Human Resource Management (Hrm) Practices On Employee Performance (A Case Of Telekom Malaysia). International Journal of Accounting \& Business Management, 2(2).

23. Mohapatra, S. (2012). Unique HR practices in the Indian IT industry: A research agenda. Delhi Business Review, 13(1), 4965.

24. Murthy, B. V. (2015). Innovative HR Practices in it Industry in India-An Empirical Study. UGC sponsored minor research project, University of Mumbai

25. Meyers, B. Y. (2005). Analysis: Corporate Case Study—Schering-Plough Looks to Remedy An Ailing Image.". PR Week, 12.

26. Omotayo, A. O., \&Adenike, A. A. (2013). Impact of organizational culture on human resource practices: a study of selected Nigerian private universities. Journal of Competitiveness, 5(4). 
27. Rana, R., \& Kapoor, S. (2016). Exploring the Contribution of Employer Branding in Corporate Image Building. International Journal of Business and General Management, 37-42.

28. Shaker, F., \& Ahmed, A. S. (2014). Influence of employer brand image on employee identity. Global Disclosure of Economics and Business, 3(3), 51-59.

29. Sparrow, P., \&Otaye, L. (2015). Employer branding: From attraction to a core HR strategy. White Paper, 15(01)..

30. Sharma, N., \&Kamalanabhan, T. J. (2012). Internal corporate communication and its impact on internal branding: Perception of Indian public sector

31. Tiwari, P., \& Saxena, K. (2012). Human resource management practices: A comprehensive review. Pakistan business review, 9(2), 669-705.

32. Tanković, A. Č. (2015, January). Interrelationship of Corporate Identity, Corporate Image and Corporate Reputation: a New Stakeholder-Time Based Model. In 34th International Conference on Organizational Science Development: Internationalization and Cooperation

33. Trehan, S., \& Setia, K. (2014). Human resource management practices and organizational performance: an Indian perspective. Global Journal of Finance and Management, 6(8), 789-796.

34. Tan, C.L., \&Nasurdin, A. M. (2011). Human resource management practices and organizational innovation: assessing the mediating role of knowledge management effectiveness. Electronic journal of knowledge management, 9(2), 155-167.

35. Turban, D. B. (2001). Organizational attractiveness as an employer on college campuses: An examination of the applicant population. Journal of Vocational Behavior, 58(2), 293-312.

36. Van Heerden, C. H. (1999). Developing a corporate image model. South African Journal of Economic and Management Sciences, 2(3), 492-508.

37. Virvilaite, R., \&Daubaraite, U. (2011). Corporate social responsibility in forming corporate image. Engineering Economics, 22(5), 534-543.

38. Wallace, M., Lings, I., Cameron, R., \& Sheldon, N. (2014). Attracting and retaining staff: the role of branding and industry image. In Workforce development (pp. 19-36). Springer, Singapore.

39. Yüksel, M. (2015). Employer Branding and Reputation from a Strategic Human Resource Management Perspective. Communications of the IBIMA, 2015, 1.

40. www.empstrack.com

41. The Economics Times, 2020

42. Bhalla, Rupa, and Pooja. Mehta. "Green Hr: The Essence for Sustainability in the 21st Century." International Journal of Human Resource Management and Research (IJHRMR) 6.1 (2016): 1-6. 